\title{
O ensino superior na vida de mulheres do Vale do Ribeira, SP: narrativas de egressas do curso de Pedagogia
}

\section{Higher education in the life of women in the Vale do Ribeira, SP: narratives of the course of Pedagogy}

\section{La enseñanza superior en la vida de mujeres del Vale do Ribeira, SP: narrativas de egresados del curso de Pedagogia}

\author{
Camila Santos Seimaru ${ }^{1}$ \\ Eliete Jussara Nogueira ${ }^{1}$
}

DOI: http://dx.doi.org/10.20435/serie-estudos.v24i51.1207

\begin{abstract}
Resumo: Narrar vidas singulares é uma forma de sensibilizar e dar visibilidade a identidades, que por vezes não são percebidas, ou valorizadas. Este estudo teve como objetivo apresentar histórias de mulheres que cursaram Pedagogia, em uma faculdade privada do Vale do Ribeira, SP. Justifica-se a pesquisa, na medida em que foi verificado não haver muitos estudos referentes ao alunado desse curso, especificamente dessa região do estado de São Paulo, e, principalmente com mulheres, com o objetivo primordial de constatar o impacto da graduação em suas vidas. Para obtenção de dados foi utilizada entrevista semiestruturada com base na história oral e realizada com alunas egressas de Pedagogia do último ano da matriz curricular 2012/2016. Ao investigar as histórias, foi possível relacionar o cotidiano escolar, mais amplo, a importância para as egressas entrevistadas adquirirem conhecimento em nível superior e as mudanças de entendimento da vida cotidiana. Esse artigo apresenta fragmentos de narrativas de três mulheres, e uma análise com as possíveis contribuições pessoais e profissionais em suas histórias de vida. Os resultados apresentam relatos de superação frente às dificuldades em estudar, questões pessoais, financeiras, e familiares, e como o ensino superior foi referência de apoio para os enfrentamentos na vida.
\end{abstract}

Palavras-chave: educação; cotidiano escolar; Pedagogia; narrativas de mulheres.

Abstract: Narrating singular lives is a way of sensitizing and giving visibility to identities, which are sometimes not perceived, or valued.This study aimed to presente histories of women who attended Pedagogy, at a private college in Vale do Ribeira, SP. The research is justified because

${ }^{1}$ Universidade de Sorocaba (UNISO), Sorocaba, São Paulo, Brasil. 
it was verified that there weren't many studies related to students from this course, specifically in this region of the state of São Paulo, and especially with womwn, with the primary objetive of ascertaining the impact of graduation on their lives.To obtain data was used a semi-structured interview based on oral history and performed with studentes who graduated from Pedagogy of the last year of the curriculum 2012/2016. In investigating the stories, it was possible to relate the broader school daily life, the importance for the graduates interviewed to acquire knowledge at a higher level and the changes of understanding of everyday life. This article presents fragments of narratives from three women, and an analysis with possible personal and professional contributions in their life stories. The results present reports of overcoming the difficulties in studying, personal, financial, and family issues, and higher education as support for confrontations in life

Keywords: education; daily school; Pedagogy; women's narratives.

Resumen: Narrar vidas singulares es una forma de sensibilizar y dar visibilidad a identidades, que a veces no son percibidas, o valoradas. Este estudio tuvo como objetivo presentar historias de mujeres que cursaron Pedagogía, en una facultad privada del Vale do Ribeira, SP. Se justifica la investigación, en la medida en que fue verificado no haber muchos estudios referentes al alumnado de ese curso, específicamente de esa región del estado de São Paulo, y, principalmente con mujeres, con el objetivo primordial de constatar el impacto de la graduación en sus vidas . Para la obtención de datos fue utilizada entrevista semiestructurada con base en la historia oral y realizada con alumnas egresadas de Pedagogía del último año de la matriz curricular 2012/2016. Al investigar las historias fue posible relacionar el cotidiano escolar, más amplio, la importancia para las egresadas entrevistadas adquirir conocimiento de la universidad y los cambios de entendimiento de la vida cotidiana. Este artículo presenta fragmentos de narrativas de tres mujeres, y un análisis con las posibles contribuciones personales y profesionales en sus historias de vida. Los resultados presentan relatos de superación frente a las dificultades en el estudio, cuestiones personales, financieras, y familiares, y la enseñanza superior fue referencia de apoyo para los enfrentamientos en la vida.

Palabras clave: educación; cotidiano escolar; Pedagogía; narrativa de mujeres.

\section{INTRODUÇÃO}

Pensando em contingências que nos fazem ser quem somos, em trajetórias que possibilitem superações, de ser outro, frente a tantos obstáculos enfrentados ainda hoje por muitas mulheres, não se pode desconsiderar as estratégias de lutas e resistências para mudar a realidade imposta às mulheres na sociedade brasileira, ainda e infelizmente, falocêntrica. Neste trabalho, procura-se evidenciar a importância do acesso à educação e ao conhecimento na vida das estudantes egressas da última turma da matriz curricular 2012/2016 do curso de Pedagogia de uma instituição privada do Vale do Ribeira, SP, região de grande beleza natural, porém considerada com o pior Índice de Desenvolvimento Humano (IDH) do estado de São Paulo, comprovado pelo Atlas Brasil (2013), Programa das Nações Unidas. A escolha 
por ouvir mulheres é que, de modo empírico, percebeu-se que as mulheres no curso de pedagogia do Vale do Ribeira buscavam um novo sentido de existir, bem como construir novos rumos, trabalho e modos de pensar em prol da autonomia feminina.

As esperanças de usar a educação como alavanca, como força suficiente para desestabilizar e, finalmente, desalojar as pressões dos fatos "sociais" parecem tão imortais quanto vulneráveis (BAUMAN, 2007). E a universidade, inserida nesse contexto de versatilidade, embora hoje não sendo a única responsável pela transmissão de conhecimento, cultura e ascensão social, continua tendo sua importância na vida das pessoas. Tem também a obrigação de um posicionamento político das práticas nela apreendidas, sobretudo quando se almeja a formação de pessoas capazes de atuar na configuração de uma sociedade melhor e que possibilite melhores condições de vida a todos, principalmente, àqueles provenientes de grupos marginalizados, como as mulheres, neste momento histórico, marcado por condições de vida adversas para grande parte da população.

A presença de mulheres em ambientes predominantemente de domínio masculino, possibilita construção de conhecimentos, processos de subjetivação que interferem na própria identidade dessas mulheres que podem se constituir em sujeitos de direitos. A relação do ensino superior e os estudantes em geral, podem ser avaliadas formalmente, mas como podemos identificar as ocorrências sensíveis a essa convivência para além dos conteúdos curriculares de formação? A intenção deste artigo não é aprofundar ou analisar estudos realizados na área de história da Pedagogia, mas, sim, uma tentativa de apontar, ou sensibilizar o leitor para histórias que rompem com destinos traçados, histórias de mulheres que começam a firmar, progressivamente, sua independência, ou seja para mostrar processos inacabados. Assim, relacionar suas conquistas e lutas ao curso de Pedagogia nos ajudará a analisar as transformações frente às demais discriminações existentes nessas instâncias. "Só então poderemos compreender que problemas se apresentam às mulheres que, herdeiras de um pesado passado, se esforçam por forjar um futuro novo" (BEAUVOIR, 1967, p. 8).

As mudanças da realidade das mulheres no Brasil e no mundo vêm ocorrendo a passos lentos, por meio de resistências desses sujeitos "menores". Sujeitos que têm procurado ocupar espaços que lhes são de direito, e as mulheres representam parte desses grupos minoritários, por isso relacionar suas conquistas e lutas ao ingresso em instituições de ensino superior e em específico ao curso de 
Pedagogia, com algumas de suas conquistas, poderá nos ajudar a entender as mudanças frente às outras discriminações existentes.

"Quem pode vigiar sonhos de moça?", já dizia Drummond de Andrade (2012). E elas sonhavam alto, queriam mais, e educar-se fazia parte desses sonhos.

As histórias entre mulheres e educação sempre andaram juntas, embora a princípio a primeira Escola Normal tenha sido destinada exclusivamente a homens, décadas mais tarde abriam-se salas femininas, o que significou um imenso passo dado à profissionalização e independência. A docência se apresentou como uma possibilidade de um trabalho remunerado com flexibilidade de horário para manter o papel social definido para mulheres, nas tarefas da casa.

[...] o que sempre se esculpiu nas vidas femininas foi um entrelaçamento de destinos incorporando sujeitos históricos aspirando por um lugar próprio no tecido social e uma profissão que se adaptou perfeitamente àquilo que elas desejavam, aliando ao desempenho de um trabalho remunerado as aspirações humanas e afetivas que sempre Ihes foram definidas pela sociedade. (ALMEIDA, 1998, p. 26).

Assim, a presença feminina nos espaços públicos foi aumentando gradualmente, mas foi na década de 60 que o movimento feminista teve seu grande marco ao apresentar, como principais reivindicações, a busca pela igualdade, escolaridade. A luta pelo reconhecimento como sujeitos da história e da ciência foi em que mais investiram as primeiras manifestantes desses grupos. Guacira Louro (2001) discute a questão da inclinação das mulheres ao magistério por serem as primeiras educadoras "naturais", portanto nada mais adequado do que lhes confiar a educação escolar das crianças. Como afirma, " para tanto seria importante que o magistério fosse também representado como uma atividade de amor, de entrega e doação. A ele acorreriam aquelas que tivessem vocação" (LOURO, 2001, p. 450).

María Jesús Izquierdo (1994) apresenta aspectos que caracterizariam certas profissões como femininas, independente do gênero de quem as executem, todas são ligadas às prestações de serviços e cuidados. Para a autora trata-se de uma atribuição social, baseada em estereótipos e preconceitos, como o caso de professoras, embora a profissão significasse mais trânsito social. Jane Almeida pondera que, mesmo com a profissão de professora estigmatizada pela caracterização feminina, foi essa possibilidade que muitas mulheres confiaram para ingressar no mercado de trabalho e serem aceitas para trabalhar fora do ambiente familiar. 
Para as professoras primárias do começo do século, o magistério foi o ponto de partida, foi o possível no momento histórico em que viveram. Significou o trânsito do invisível para a visibilidade e a realização de alguma coisa, que não o pouco prestigiado serviço doméstico. Repito: que conquista poderia ser melhor? O magistério era o trabalho intelectual e assalariado sem conotação pejorativa, era o estatuto conferido pelo conhecimento e pelo uso da inteligência. Tinha o poder de conceder uma palavra mais abalizada num meio ignorante. Conferia mobilidade social, mais liberdade pessoal e respeito entre as classes trabalhadoras. (ALMEIDA, 1998, p. 211).

Registrar a história das mulheres na educação configura-se em tirar do anonimato professoras que se encarregam, no país, da educação fundamental, apesar das dificuldades enfrentadas como mulheres e como profissionais. Entre os motivos de mulheres terem procurado a carreira docente, destaca-se a necessidade financeira, e a busca de realização profissional ou pessoal. As mudanças do século XX, com a industrialização e a urbanização crescentes, favoreceram a emergência de movimentos feministas, e suas reivindicações por direitos foram outros aspectos que levaram as mulheres a vislumbrar um futuro com maior liberdade e menos opressão.

Viver uma vida inteiramente privada significa, acima de tudo, estar privado de coisas essenciais a uma vida verdadeiramente humana: estar privado da realidade que advém do fato de ser visto e ouvido por outros, privado de uma relação "objetiva" com eles decorrente do fato de ligar-se e separar-se deles mediante um mundo de coisas, e privado da possibilidade de realizar algo mais permanentemente que a própria vida. A privação da privatividade reside na ausência de outros; para estes, o homem privado não aparece, e, portanto, é como se não existisse. O que quer que ele faça permanece sem importância ou consequência para os outros, e o que tem importância para ele é desprovido de interesse para os outros. (ARENDT, 1991, p. 72).

São notórias as diferenças entre professoras do passado e agora, mas não se pode deixar de minimizar a atuação de ambas em suas resistências aos padrões impostos nem desqualificá-las como sujeitos históricos, colocando-as como vítimas da sociedade, o que faz com que a profissão e essas mulheres sejam cada vez mais desmerecidas. Também considera-se que, a partir de falsos pressupostos sobre a inserção das mulheres no magistério, pode-se produzir efeitos danosos nas análises decorrentes, desvirtuar a compreensão e atribuir ao trabalho docente feminino elementos desqualificativos para um mercado capitalista. 
Almeida (1998) aponta ainda que o discurso vitimizador, comum em alguns estudos educacionais, ao enquadrar as mulheres nos conceitos pré-definidos socialmente sempre como oprimidas, esquece-se de que existem os contrapontos que se situam nas entrelinhas da História e ancoram-se no mundo subjetivo, local de trânsito das mulheres, por excelência. Será que, em vez de se fazer sempre uma história de opressão e submissão, enfim uma história de vencidas, "no caso das mulheres no magistério, esta não é uma história de vencedoras?” (ALMEIDA, 1998, p. 80).

Perceber, em histórias singulares, atitudes de enfrentamento ao destino pronto e, por vezes, fatalítico foi o objetivo desta pesquisa. Para tanto, optou-se pela metodologia da História Oral, utilizando de entrevistas semiestruturadas, para mostrar a trajetória das estudantes de Pedagogia do Vale do Ribeira, SP, no cotidiano escolar universitário. Entrou-se em contato com egressas do curso para o convite em participar da pesquisa e seguir os procedimentos éticos; para este artigo, será apresentado o relato de três. Esse procedimento como alternativa metodológica apresentou-se como importante, pois, quando é proposto ouvir e analisar aspectos de histórias de pessoas, dá-se a elas, enquanto sujeitos, uma valiosa contribuição para o entendimento da realidade investigada. Porém transitar entre histórias e adentrar na vida dessas mulheres exige sensibilidade.

As fontes orais, pela sua subjetividade, mais do que nunca, necessitam de um discernimento objetivo que permita desvendar, nas histórias de vida recuperadas pela memória, aquilo que se propõe estudar. Os anos e as épocas transcorridos não têm limites demarcados por este ou aquele fato simplesmente, e, quando se trata de desvendar mentalidades e ideologias, isso ainda é mais complexo, pois, apesar das datas significativas, dos fatos extraordinários, dos atores que se destacaram em determinados períodos, a vida cotidiana sempre transcorreu na rotina, nos atos simples de viver e lutar pela sobrevivência. (RAGO, 2013, p. 106).

É por meio da história que as pessoas procuram compreender as revoluções e mudanças das suas próprias vidas e, quando utilizada como matéria-prima, aquela ganha nova perspectiva. "A cena do testemunho, o face a face, a constelação de forças do presente deixam suas marcas no testemunho, tanto quanto a perspectiva dos fatos, a entonação da voz, os silêncios e os gestos de quem fala" (RAGO, 2013, p. 19).

Assim, a metodologia escolhida foi o instrumento necessário para fazer valer, prioritariamente, as palavras ditas e silenciadas pelas egressas em questão. 
Para manter o sigilo da identidade das mulheres entrevistadas nesta pesquisa, os nomes foram substituídos pelos de estrelas, inspiração do livro de Clarice Lispector "A Hora da estrela". Na obra de Lispector, ao mesmo tempo em que é visível a brutalidade do mundo no qual vivemos, revela-se também delicadeza. A vida mostrada como o que ela é, segue a si mesmo; medos são superados e transcende-se a realidade.

Que não se esperem, então, estrelas no que se segue: nada cintilará, trata-se de matéria opaca e por sua própria natureza desprezível por todos. É que a esta história falta melodia cantabile. O seu ritmo é às vezes descompasso. E tem fatos. Apaixonei-me subitamente por fatos sem literatura - fatos são pedras duras e agir está me interessando mais do que pensar, de fatos não há como fugir. (LISPECTOR, 2007).

Lispector (2007, p. 24) assinala: "Os fatos são sonoros, mas entre os fatos há um sussurro. É o sussurro que me impressiona". Indo pelo mesmo pensamento, Walter Benjamin (1985) fala sobre o silêncio que o assusta, mas que também pode a vir ser ativo e criativo na concretização das narrativas. "A narração, em seu aspecto sensível, não é de modo algum o produto exclusivo da voz. Na verdadeira narração, a mão intervém decisivamente, com seus gestos [...] que sustentam de cem maneiras o fluxo do que é dito" (BENJAMIN, 1985, p. 220).

\section{A HORA DAS ESTRELAS: NARRATIVAS DE EGRESSAS}

E assim como Macabéa, personagem do livro de Lispector, as participantes desta pesquisa são todas estrelas:

Dalva, 29 anos, separada, mãe de três filhos, não atua na área;

Lira, 30 anos, casada, mãe de um filho, não atua na área de formação; e

Ursa Maior, 38 anos, divorciada, mãe de duas filhas, atua na área eventualmente e não tem curso de especialização na área.

Estrela Dalva teve seu ingresso na faculdade por acaso aos 26 anos. Vida difícil, começou a trabalhar cedo, casou cedo, foi mãe cedo, conheceu o abandono cedo e descobriu as mazelas do mundo cedo demais.

Minha vida sempre foi bem complicada, meu pai é pedreiro, minha mãe era dona de casa e então eles se separaram e nós muito novos quando eles se separaram, a gente tinha uns 13 anos, eu fiquei morando só com meu pai, então era meu pai, eu e mais quatro irmãos homens, aí como meu pai 
era pobre, e homem não supria as necessidades que uma menina precisa, então comecei a trabalhar cedo em casa de família, de empregada e cuidar de crianças e assim foi indo [...] Tem uma vizinha minha que é professora e ela sempre falava para eu fazer algum curso, e eu sempre falava que aquele momento não era o certo, porque eu tinha uma bebê e estava grávida ainda e pensava em deixar isso para mais tarde e assim foi indo. [...] mas, um dia, fiz o cadastro, no outro dia paguei o boleto, e foi aí que contei para meu marido. Ele ficou meio assustado e falou: "não, não faça, deixe esse negócio quieto" e eu disse: "não, eu vou fazer" e fiz [...] Chegou o dia do vestibular, fui fazer e fiquei naquela expectativa de "passou ou não passou" porque eu fiquei 10 anos sem fazer curso nenhum depois que eu terminei meu ensino médio, então eu não tinha noção nenhuma do que eu estava fazendo, dei minha cara à tapa, não estudei, não fiz nada e fui.

A narrativa de Dalva, além de sua própria caminhada, apresenta a vizinha, mulheres incentivando mulheres a estudar. Conquistada a aprovação no vestibular e passada a euforia da nova conquista, a angústia surgiu: como é que os valores das mensalidades irão ser custeados?

Quando chegou a aprovação, eu fiquei extasiada e daí "cadê o dinheiro para fazer a matrícula?", eu não tinha, foi quando meu pai falou que daríamos um jeito e fomos juntando um dinheirinho daqui, outro dali e assim conseguimos fazer a matrícula. [...] a família inteira ajudou até eu conseguir a bolsa, através do Programa Escola da Família, foi o esforço da família inteira para eu conseguir.

Fica nítida em suas falas quando faz referência à entrada na faculdade o suporte familiar como uma conquista de todos. Dalva foi a primeira pessoa da família a ter concluído uma Faculdade, percebemos que a palavra "nós" é utilizada constantemente. Apesar de hoje não estar mais casada, menciona a fundamental colaboração do ex-marido para que ela conseguisse concluir a graduação, apesar de, no início, ele ter se mostrado receoso quanto ao novo projeto da mulher. A aceitação do marido veio com sentimentos de medo, um conflito comum numa sociedade machista. A dificuldade para conseguir arcar com as mensalidades nos primeiros meses não foram as únicas barreiras enfrentadas, o deslocamento até a faculdade, a interação com novas pessoas, número de alunos na sala, relação com professores, enfim um ambiente que privilegia o intelecto, pode ser intimidador, o que nos faz refletir sobre como planejamos todo o ambiente escolar. 
No começo da faculdade, foi muito estranho, tinha um recém-nascido em casa, eu tinha que pegar ônibus e eu não tinha dinheiro para pagar as passagens de ida e volta para ir até a faculdade que ficava em outra cidade, então eu fui até a prefeitura, conversei, fiz um cadastro e consegui passes que pagavam a metade da passagem, e meu marido com muito esforço ajudava com o restante. [...]

Assim comecei a ir, frequentar o curso, e pense, aquela sala cheia de alunos, mais de 100, todos desconhecidos, gente que nunca tinha visto na minha vida e eu ali, não sabia de nada, foi bem complicado, sentei bem no cantinho na parede, escondida e eu pensava em desistir, porque tudo era novo, as matérias novas: português, história, não sabia o que era leitura e escrita, essas coisas, até já conhecia, mas descobri que não sabia nada, os professores falavam, e eu ficava desesperada, mas com o tempo fui aprendendo a absorver da melhor forma possivel, e a maneira como os professores conduziam as aulas me ajudaram a aprender e gostar daquilo, e hoje me sinto professora e preparada para exercer a função, mas quero evoluir mais.

O primeiro semestre foi bem difícil como falei, no segundo também, e no terceiro foi que o negócio começou a fluir melhor, comecei a entender meIhor, o relacionamento com os professores melhorou, com os colegas de sala também, porque também foram diminuindo os alunos na sala.

A escolha em cursar Pedagogia se deu por influência de uma colega (outra mulher) e revela que não era a primeira opção, gostaria de enfermagem, mas o custo alto da mensalidade por vezes é o grande influenciador das decisões na escolha de uma profissão. As contribuições do curso são, a todo o momento, ressaltadas por ela, desde a relação com filhos, família e autoestima.

O curso contribuiu muito para a minha vida, na relação com meus filhos, com outras crianças, outras pessoas, hoje eu vejo que eu falo melhor, que me expresso melhor, escrevo melhor, sou melhor em tudo hoje.

Até a relação com a minha familia melhorou, eles não tinham esperança. Eu sou a única formada na família, na família inteira sou a única graduada, com diploma universitário e então o presente não foi só meu, foi deles também. Só na faculdade que aprendi de verdade, me ensinar a me descobrir e a descobrir de qual forma eu consigo entender e aprender e principalmente a focar e me concentrar.

Estrela Dalva conta que levou os ensinamentos aprendidos para dentro de seu lar, que na família há casos de autismo (um sobrinho) e, mesmo convivendo com essa realidade de perto, confessa que não entendia muito bem do que se 
tratava e da dificuldade de se trabalhar essa questão. Reconhece que, na disciplina sobre educação especial, é que adquiriu conhecimentos que ajudaram a família a entender os comportamentos que ele apresentava. Outras disciplinas também foram destacadas por ela como fundamentais para que se reconhecesse como mulher e sujeito autônomo, capaz de construir seu próprio caminho, com principal enfoque para os temas transversais, em especial sobre racismo.

Outro ponto muito marcante foi quando tivemos aulas sobre cultura indígena e afro-brasileira, eu sou de uma família mista, meu pai é italiano, branco e minha mãe é negra e sempre sofri muito na escola, antigamente a gente não falava muito sobre isso, não tinha esse negócio de falar que era bullying e toda essa movimentação que tem hoje ao falar disso, e acabava que a gente não ligava muito e levava na brincadeira, mesmo sofrendo com isso escondido; foi somente quando o assunto foi abordado na faculdade, que fui ver que tudo que eu e meu irmão passávamos era preconceito, era preconceito na escola, porque na minha família são três irmãos brancos e três negros e os negros eram taxados e é até chato de falar, mas a gente não entendia. A gente tinha perna ressecada, e passava óleo de cozinha na perna, e os outros tiravam sarro. [...] Lá a gente tratava de temas transversais, que eu nunca tinha pensado antes, como o papel da mulher, além do meio ambiente, raça, homossexualismo, e percebi que ser mulher é não depender de homem nenhum, é ir atrás dos seus objetivos, lutar, a mulher consegue ter tudo, cada um tem seu espaço, seu lugar é só seguir em frente, independente, tem que ir atrás, lutar. [...] Nunca fui comunicativa, mas, depois que entrei na faculdade, comecei a conversar com todo mundo e me soltar, eu não tinha coragem de olhar no olho da pessoa para falar, eu tinha medo, vivia com a cabeça baixa, com medo de alguma coisa, hoje em dia eu falo, sou autoconfiante. [...]. Meu marido começou a ficar com ciúmes, ainda mais porque, antes de eu fazer faculdade, eu não me arrumava, não ligava para maquiagem, não colocava um batom, não colocava um brinco, nem a sobrancelha eu fazia para você ter uma ideia, depois eu fui vendo que eu precisava me arrumar, todo mundo ia bem arrumado para faculdade, bem bonito e cheiroso, e falei: "também quero", e comecei a ver isso e absorver para mim também, e meu marido foi vendo que eu fui ficando mais arrumada, e ele falou: "peraí, o que está acontecendo lá, pra ela mudar desse jeito?

[...] E hoje não, [...], me divirto e agora não tenho medo de ser feliz, vou e faço acontecer, não espero mais.

A narrativa que Estrala Dalva apresentou foi de transformação, gradual, por meio do conhecimento, da troca de experiências com outras pessoas, que só foram possíveis no ambiente da educação superior. 
Outra Narrativa é de Estrela Lira, que se formou no mesmo ano de Estrela Dalva; à época da entrevista, trabalhava como professora em uma instituição de ensino pública e como professora particular de reforço. Estrela Lira tem histórico de rejeição e discriminação em toda sua vida, mas, acima de tudo, de superação.

Foi abandonada pelo pai, presidiário, ainda na barriga da sua mãe, pois dizia ser uma gravidez indesejada e, logo que nasceu, deixada aos cuidados da avó materna quando a mãe foi para outra cidade tentar uma nova vida. Criada pelos avós cresceu em meio a homens: tios, primos, avô, todos brancos, pois quem tinha características negras, era o pai, mas conta que quem mandava mesmo dentro de casa era a avó, mulher forte e trabalhadora que foi gari durante toda a vida e assim criou filhos e netos.

Tive vários problemas durante minha vida... emocionalmente, socialmente, eu nasci sem pai e, logo que eu nasci, minha mãe foi morar em outra cidade, então eu fiquei com a minha vó, sempre senti falta deles, lógico [...] não ter pais presentes para tirar suas dúvidas, pra responder algumas coisas que você precisava, e isso sempre foi ruim pra mim. [...] Tenho mais dois irmãos por parte de mãe e sou a única negra da família, meu pai que era negro, e sempre vivi numa família de brancos e muito machista, mas "se ferraram comigo" porque aprendi a não deixar mandarem em mim, porque quem mandava lá em casa era minha vó.

Lira cresceu ouvindo sempre que não era capaz e ia ser como o pai, por isso, conta que sempre precisou provar todos os dias o contrário. Sozinha foi em busca de novas oportunidades e novos sonhos, fez vários cursos, todos oferecidos gratuitamente por instituições públicas ou privadas e, assim, começou sua carreira como professora. Em um desses cursos, aprendeu taekwondo e, como foi aluna aplicada, logo ganhou a confiança do mestre e passou a ministrar aulas para crianças, ao mesmo tempo em que repassava tudo o que tinha aprendido em outras entidades filantrópicas a outras crianças assistidas. Embora sofrendo de discriminações, Lira reagiu se ocupando e estudando.

Sofri bastante preconceito por ser negra, na escola assim sempre colocaram apelidos, falavam que minha inteligência era inferior às pessoas brancas, as professoras quando estava estudando em São Paulo, era escola de pessoas de classe mais abastada e a professora sempre falava alguma coisa que me deixava mal, tinha uma menina que sempre me chamava de preta e me deixava mal, me afetava bastante, mas isso sempre me dava mais vontade de aprender. Tanto é que na minha adolescência eu não vivi igual aos outros 
adolescentes, todo dia ia atrás de algum curso pra fazer e era o dia inteiro, toda minha adolescência passei assim.

Revisitando o depoimento de Estrela Lira, percebe-se o quanto para ela é importante dar a outras crianças oportunidades de crescimento, assim como para ela foi dada, principalmente àquelas que estão mais vulneráveis. Foi a partir dessas ações que ela se reconheceu como professora, fato também percebido pelos que estavam em sua volta. Sua melhor amiga, que também é professora, foi sua maior incentivadora. Em sua narrativa, Estrela Lira sempre deixa evidente seu orgulho em ser professora, em conquistar um diploma superior e trabalhar na área, apesar de deixar bem claro que, desde muito cedo, teve que trabalhar fora para ajudar nos custeios da casa. Emocionada, lembrou os momentos vividos na faculdade, do bom relacionamento com colegas e professores, principalmente do dia da colação de grau, que contou com a presença do marido, filho, avó, irmão e sua mãe que, vendo como a filha falava do curso de maneira contagiante, decidiu seguir o mesmo caminho e viu na Pedagogia uma oportunidade.

Minha mãe foi fazer Pedagogia também, quando eu comecei, eu me empolguei, gostei e comecei a contar tudo que eu estava aprendendo e ela decidiu fazer também o mesmo curso, e termina no final desse ano. Ela é também bem empolgada com o curso, antes ela era doméstica e agora já está dando aula num projeto social.

[...]

Minha vó falou que queria ser como eu, que queria aprender tudo que eu aprendi, mas que ela não pode e que hoje ela se sente realizada em mim e que sou seu orgulho, mas antes de eu entrar na faculdade, quando eu era menor ela sempre falava que eu não ia dar coisa boa, que eu era muito rebelde, falava que eu ia ser igual meu pai e que eu ia acabar presa igual ele e que se não fosse ela era pra eu estar na lata de lixo.

Refletindo sobre todo o processo de transformação que o curso trouxe para sua vida, apesar de contratempos vividos, como a incerteza de conseguir arcar com as despesas das mensalidades antes de ser viabilizado o financiamento estudantil, afirma que a graduação foi sua melhor escolha por ter concluído uma escalada que vem desempenhando desde sua infância: em provar aos outros e para si mesma que pode tudo, desde que ela queira, obviamente.

Eu sou a primeira a ter curso superior na família e agora que concluí me vejo, primeiramente, como uma pessoa mais forte, uma mulher mais forte, 
que eu sei da capacidade que eu tenho, eu sei que eu consigo porque eu entrei pra me desafiar, eu gosto de desafio e como as pessoas sempre me subestimaram, então eu entrei e queria ser a melhor, não sei se eu fui, mas eu tentei e esse curso contribuiu pra isso, me fez melhor em todos os sentidos, mais independente, mais forte, hoje, se eu quero alguma coisa eu sei como correr atrás, como conseguir, eu sei que eu tenho a capacidade de fazer, de me defender também. Hoje eu me sinto poderosa e sei que só depende de mim, que eu não dependo de ninguém.

Quando Estrela Lira narra sua história, outro aspecto que sempre é ressaltado, o fato do curso ter possibilitado uma condição financeira melhor, apesar de sempre trabalhar em diversas áreas, conseguiu um estágio bem remunerado na área da pedagogia e, a partir dessa oportunidade, outras melhores apareceram; conta que pôde vivenciar na prática o que aprendia na faculdade e ainda acrescenta o valioso aprendizado durante essa experiência que a ajudou a entender melhor seu filho e ajudá-lo nas tarefas escolares e cotidianas. Em seus apontamentos, relembra momentos complicados, principalmente no relacionamento com o marido, devido às ausências diárias, tempo e dedicação às atividades que a graduação requeria e a certa insegurança causada pelo fato de a mulher possuir algo a mais que ele; como o diploma de uma faculdade. Novamente nessa narrativa, a presença do comportamento machista, insegurança pela possível diferença na escolaridade.

A última narrativa é da Estrela Ursa Maior, que entrou para a faculdade com 35 anos acompanhada de sua irmã com 40, esta já avó, sempre onde uma estava, a outra estava lá ao lado, uma apoiando a outra (mulheres se apoiam), incentivando, mas infelizmente a irmã acabou não concluindo o curso em 2016, devido a algumas dependências de matérias, mas continuou a acompanhá-la até o último dia de aula e, assim, descobriram algo novo para elas: um mundo cheio de possibilidades.

Divorciada e recém-saída de um relacionamento que deixou cicatrizes, tomou coragem, com apoio dos pais e irmã de mudar de cidade, de emprego e, principalmente, mudar de vida. Veio para o Vale do Ribeira ainda criança; quando adolescente, frequentando o Ensino Médio, ficou grávida e casou. Com filha pequena, marido e casa para cuidar, não deu continuidade aos estudos naquela época, mas, quando decidiu que iria cursar uma faculdade, não teve o apoio da família; queria fazer Educação Física, mas segundo ela, diziam que não era curso 
para mulher fazer, então os planos de cursar uma faculdade foram sendo adiados; outra filha veio e as prioridades passaram a ser outras.

Sempre tive uma vida tranquila, meu pai veio pro Vale do Ribeira quando eu tinha cinco anos, ele comprou a loja da minha tia, e comecei a ajudar desde muito cedo, desde criança a gente ficava na loja ou em casa ajudando, e assim foi até os meus 17 quando eu fiquei grávida da minha filha; eu estava no 1 o colegial e, como fiquei meio assustada, acabei perdendo o semestre, mas voltei no semestre seguinte e concluindo os estudos, mesmo grávida e depois com a bebê. [...] Aí parei meus estudos no ensino médio, na verdade, na minha casa, todo mundo casou muito cedo, minha irmã casou com 15 anos, também foi mãe, minha irmã do meio também foi mãe com 19. Não que a gente não soubesse, mas não tinha essa relação mais aberta para conversar sobre engravidar e meios de prevenir como tenho hoje com a minha filha.

Conta que sempre gostou de estudar, prestou provas para alguns concursos públicos e conseguiu um cargo como inspetora de alunos em uma escola na região de Sorocaba. Sua vida estava definida: marido, filhas, um emprego público. Entretanto a vida não é uma constante, quando tudo parecia certo, dúvidas e incertezas começaram a brotar e, nesse período, decidiu se divorciar e engatou um novo relacionamento que acabou de maneira traumática e, vendo a situação da filha, sua mãe interveio.

Nesse período eu me separei, foi em 2011 e, depois disso, eu tive outro relacionamento, só que eu tive uma decepção muito grande e foi muito traumático, fiquei muito mal e minha mãe, vendo a minha situação, não deixou eu ficar lá. Ela me convenceu a vir embora pro Vale e foi aí que ela me falou: "Você vai fazer faculdade". Eu tinha 35 anos, e tudo foi mudando. Cheguei em outubro, e fevereiro já estava estudando.

A escolha em cursar uma faculdade, na verdade, partiu da mãe, que, vendo a filha mal, decidiu mudar o rumo da situação; já a escolha em fazer Pedagogia partiu dela, por já trabalhar na área como inspetora durante anos, percebeu que esta poderia ser a opção mais acertada e, para ter mais estímulo em frequentar um curso superior no momento delicado que estava vivendo, contou com o apoio da irmã mais velha, que também não tinha o ensino superior.

Na verdade escolhi Pedagogia, por ter trabalhado na creche e como inspetora, eu sempre quis fazer Educação Física, só que na época, meu marido 
não deixou, e não tive forças para lutar contra, e agora eu me achava velha demais. Mas de qualquer forma iria ser professora.

Fiquei sem estudar 15 anos por uma série de motivos: filhos, marido, emprego, mas, quando resolvi fazer para sair daquilo que estava vivendo, chamei minha irmã que estava com mais de 40 anos, já era avó, eu estava com 35, e uma incentivou a outra, até brinco que não arrumei namorado na faculdade, porque todo mundo pensava que a gente era um casal, a gente não se desgrudava. Ela foi também para me acompanhar, foi muito minha parceira, sempre estudando juntas. Nós éramos chamadas de "as irmãs cajazeiras".

Para começar a viver uma nova vida, teve que deixar uma das filhas em Sorocaba, pois na época, a menina fazia curso pré-vestibular e, enquanto a mãe cursava Pedagogia, a filha também ingressou no ensino superior. A filha mais nova veio junto e ficava com os avós durante à noite, enquanto Ursa Maior ia para faculdade.

Minha mãe ficava com minha filha mais nova para eu ir estudar à noite, $e$ minha outra filha ficou em Sorocaba, com meu ex-marido, por conta dos estudos, ela fazia cursinho pré-vestibular e, durante a minha graduação, ela entrou para a faculdade de odontologia com bolsa de estudos. Foi complicado deixar minha filha lá e vir, talvez até por uma fraqueza minha, mas eu não estava conseguindo me reestabelecer emocionalmente lá da mesma forma como eu consegui aqui, lá eu fiquei muito mal mesmo. Cheguei ao ponto de não sair mais de casa, me vi numa situação que eu nunca imaginei que alguém pudesse chegar e, por isso ela, minha filha, me cobrava demais por não ter ficado lá, mas eu precisava vir, fazer tudo que eu fiz, estar mais forte para poder voltar.

A adaptação à nova realidade foi sendo feita aos poucos, lembra ao chegar ao primeiro dia de aula, com a sala repleta, de mulheres, com idades distintas o que gerou um estranhamento, afinal, eram muitos anos fora do ambiente escolar, como aluna. Para ela, cursar a faculdade nesse período da sua vida foi oportunizador e, melhor aproveitando, abriu novas possibilidades. Realizou provas seletivas com resultados positivos, participou de eventos dentro e fora do espaço escolar que contribuíram para experiências significativas e nunca antes experimentadas.

Eu mudei minha vida, talvez eu ficasse lá para sempre como inspetora, acomodada e não ia sair daquilo nunca mais, cuidar das meninas. Sei que não vou ficar rica como professora, professor não ganha tanto quanto mereça, 
mas você pode ver, a maioria dos professores consegue ter uma casa, um carro, é uma oportunidade de eu melhorar.

$[\ldots]$

Então a mudança de cidade e a faculdade serviram para eu dar uma guinada na minha vida e mudar, não só emocionalmente, querendo ou não, com a graduação eu posso ter outras perspectivas, abre mais portas. Hoje sou independente, tenho meu espaço, cumpro meu papel de filha, de mãe, estou na melhor fase como mulher.

Durante a entrevista, Ursa Maior se emocionou diversas vezes, ao relembrar toda sua trajetória, os sacrifícios para chegar até o fim do curso, porém mostrou-se extremamente realizada por tudo que vem conquistando ao longo desses últimos anos e outras oportunidades que estão por vir. A todo o momento, pude notar o olhar de esperança ao descobrir novamente um mundo novo cheio de possibilidades.

As narrativas aqui apresentadas mostram que cursar o ensino superior em Pedagogia (ou outro curso) não significa apenas adquirir conhecimentos, e correlacionar fatos, mas, acima de tudo, compreender os valores e o significado da vida como um todo. Foi possível observar que, durante o processo de entrevistas, essas mulheres foram ressignificando a sua própria vida; entregaram-se às rememorações, recriaram e falaram de um tempo ainda presente em suas memórias e que permitiu a construção de novos saberes e experiências, que se multiplicaram definindo e redefinindo outras formas de ser, pensar, agir, sentir, que também são coletivas. Assim, foram conferindo sentido à existência, no balanço vivido no cotidiano escolar superior e além dele. A principal força motivadora dessas egressas estava na crença de um poder que adquiriram por meio da instrução e vivência dentro do cotidiano escolar universitário. Percebe-se que esse poder possibilitou a apropriação de maiores consciências e oportunidades de acesso aos direitos públicos e privados, e daí a relevância em ouvi-las e descortinar as formas como (re)direcionaram suas vidas após a escolha de cursar o ensino superior.

Na perspectiva de gênero, foi possível reconhecer a referência à tendência feminina de ser alguém para o outro, para a família, principalmente, definida por Beauvoir (1967), a realização associada à possibilidade de ajuda e do serviço; por outro lado, a ênfase na emoção também se coaduna com a imagem construída da mulher, a quem é permitido não apenas o sentir, como também expressar as emoções. A ênfase na subjetividade, por exemplo, é um dado novo na formação 
das alunas de Pedagogia, que as torna, presumivelmente, mais competentes e mais conscientes do seu papel social, contribuindo, dessa forma, para o seu crescimento, poder, status social, conscientização, resistência, emancipação e libertação. Outro aspecto apontado é o curso como possibilidade de uma carreira profissional compatível com a vida familiar.

A partir das narrativas, pode-se depreender, ao assumir claramente, a prioridade que as mulheres dão à vida familiar, inclusive em detrimento de sua inserção imediata na vida universitária e profissional. Beauvoir (1967) ao analisar que as mulheres não são criadas como livres, são destinadas à tutela mesmo que, algumas vezes, sem ousar rebelar-se, se submetam, de modo consciente, a alguém ou a alguma situação.

Se quisermos realmente conhecer o conhecimento, saber o que ele é, apreendê-lo em sua raiz, [...], devemos compreender quais são as relações de luta e de poder. E é somente nessas relações de luta e de poder - na maneira como os homens entre si se odeiam, lutam, procuram dominar uns aos outros, querem exercer, uns sobre os outros, relações de poder - que compreendemos em que consiste o conhecimento. (FOUCAULT, 2003, p. 23).

\section{CONSIDERAÇÕES FINAIS}

Através desses depoimentos das estrelas egressas de Pedagogia do Vale do Ribeira, SP, impregnados de significações, podemos considerar ser possível a emancipação pelo conhecimento. Essas mulheres parecem ter alcançado um "acontecimento" em suas vidas, com uma nova perspectiva de ser e agir ao se perceberem sujeitos capazes de fazer suas próprias escolhas, mulheres essas que fizeram do aprendizado sua liberdade e começam a afirmar concretamente sua independência, mas não sem dificuldades que conseguem viver sua condição de ser humano. Nessa perspectiva, é plausível afirmar que, assim como outros cursos de graduação ou Pedagogia (apesar de todo preconceito ainda existente contra as licenciaturas), se possibilita crescimento social, financeiro e, principalmente pessoal, como podemos observar nos depoimentos de todas as egressas, ao conceber a vida dessas mulheres após a vivência no cotidiano escolar universitário como acontecimento gerando novos movimentos, concepções diferentes a partir do encontro com o outro e que se produz como um devir. 
Na filosofia de Heráclito, o devir é exemplificado pelas águas de um rio, que continua o mesmo, a despeito de suas águas continuamente mudarem: O mesmo homem não pode atravessar o mesmo rio, porque o homem de ontem não é o mesmo homem de hoje, nem o rio de ontem é o mesmo de hoje. Tudo que existe é conduzido pelo fluxo (MARCONDES; JAPIASSÚ, 1996).

Devir é estar sempre compondo em nossos corpos algo singular, embarcando constantemente em possíveis linhas de fuga desterritorializantes, uma multiplicidade de acontecimentos que nunca cessam de assediá-lo e de gerar efeitos distintos em sua vida. É, enquanto movimento, uma compreensão diferenciada de liberdade e criação. É estar traçando para si novas singularidades a cada encontro, e não apenas tolerar o outro ou mesmo desenvolver com ele única e exclusivamente um elo. Gilles Deleuze e Félix Guattari (1997, p. 18) apontam ser o devir não uma correspondência de relações, mas tampouco ele é uma semelhança, uma imitação e, em última instância, uma identificação. "[...] O devir não é uma evolução, ao menos uma evolução por dependência e filiação. O devir nada produz por filiação; toda filiação seria imaginária. O devir é sempre de uma ordem outra que a da filiação. Ele é da ordem da aliança".

Outra visão positiva que as entrevistadas têm do curso decorre também do fato de oferecer oportunidade de aproximação com temas como meio ambiente, igualdade de gênero, raça, credo, etnia, multiculturalismo, diversidade, subjetividade e todos. De acordo com Silvio Gallo (2013), os aspectos do cotidiano escolar que contribuem para aprendizagens sociais relevantes, entre outros, é educação menor, aquela desenvolvida nas salas de aula; a que também ultrapassa os limites físicos da sala de aula, das leis, das políticas e das determinações legais; ela contempla o plano micropolítico de criação e produção. Pode-se considerar que esse movimento político e pedagógico contribuirá para a ressignificação da escola, principalmente da escola à qual os que vêm das margens têm acesso. Nesse sentido, a principal contribuição política ocorre na construção e ampliação da noção de cidadania na qual o sentimento de pertencimento e a intervenção cotidiana são prioritários.

Como bem assinala Pedro Goergen (2005), na medida em que construímos "outros" em nosso cotidiano, visto que o ser humano pode ser entendido como um ser multifacetário que busca incansavelmente corrigir-se para superar suas limitações, o ser humano vive em um processo contínuo de construção: "é um 
'ser a caminho de si mesmo' e ele é o único que pode percorrer esta estrada" (GOERGEN, 2005, p. 84).

As vivências extra sala de aula, somadas às experiências mais formais dentro do ambiente escolar através das interações com professores e colegas, se constituem em elementos enriquecedores, não somente para o exercício da profissão, mas também para a vida particular. Os depoimentos revelaram a importância dessas experiências como atividades e excursões no campo, atividades socializadas, atividades individuais e interdisciplinaridade para a vida das entrevistadas, enquanto cursavam Pedagogia, possibilitando a elaboração da experiência humana de forma crítica e criativa.

Bernard Lahire (1997) aponta que é importante avaliar que as condições de existência de um indivíduo estão também atreladas a todo um contexto social, escolar e, principalmente, familiar onde ele está inserido, que vem da ordem moral e material doméstica que se traduz em cognição, mesmo que não inteiramente intencional e consciente através de intercâmbios cotidianos que definem o lugar simbólico da escolarização. No plano social, o que se pode observar nesse caso é a figura central e responsável pelo ingresso e engajamento no ensino superior: a mãe ou outras figuras femininas; mulheres fortes que, através de comportamentos adotados em situações singulares, tiveram o grande mérito de alguma forma viabilizar e favorecer o processo educacional dessas estudantes, sendo de extrema importância considerar o gênero como elemento implicado nas maneiras de mobilização para a valorização e formação escolar.

O papel fundamental da Educação é concebido como um processo humano e social pelo qual o ser o humano se faz, fazendo o mundo e a história por não ser um empreendimento neutro; o educado é sujeito ativo no processo e está inteiramente envolvido, de modo consciente ou não, num ato político como aponta Gallo (2013), e se constitui em um trunfo desencadeador de seu crescimento pessoal.

Assim como Macabéa, a Estrela, personagem principal da obra de Lispector, essas mulheres estudantes de Pedagogia do Vale do Ribeira, descobriram um futuro através do conhecimento, das palavras: "Macabéa ficou um pouco aturdida sem saber se atravessaria a rua, pois sua vida já estava mudada. E mudada por palavras- desde Moisés se sabe que a palavra é Divina. Até para atravessar a rua ela já era outra pessoa. Uma pessoa grávida de futuro" (LISPECTOR, 2007, p. 79). 


\section{REFERÊNCIAS}

ALMEIDA, Jane Soares de. Mulher e educação: a paixão pelo possível. São Paulo: Editora UNESP, 1998. (Prismas)

ARENDT, Hannah. A condição humana. Tradução de Roberto Raposo. Rio de Janeiro: Forense Universitária, 1991.

ATLAS DO DESENVOLVIMENTO HUMANO NO BRASIL. 2013. Disponível em: https://www. undp.org/content/dam/brazil/docs/IDH/Atlas\%20dos\%20Municipios/undp-br-idhm-dobrasil-2016.pdf. Acesso em: 6 jul. 2016.

BAUMAN, Zigmunt. Vida líquida. Rio de Janeiro: Jorge Zahar, 2007.

BEAUVOIR, Simone. O segundo sexo 2: a experiência vivida. Tradução de S. Milliet. 2. ed. São Paulo: Divisão Europeia do Livro, 1967.

BENJAMIN, Walter. O narrador - considerações sobre a obra de Nikolai Leskov. In: BENJAMIN, Walter. Magia e técnica, arte e política. São Paulo: Brasiliense, 1985.

DELEUZE, Gilles; GUATTARI, Félix. Mil Platôs: capitalismo e esquizofrenia. Rio de Janeiro: Editora 34, 1997. v. 4.

DRUMMOND DE ANDRADE, Carlos. Contos de aprendiz. São Paulo: Companhia das Letras, 2012.

FOUCAULT, Michel. A verdade e as formas jurídicas. Rio de Janeiro: Nau, 2003.

GALLO, Silvio. Deleuze \& a educação. 3. ed. São Paulo: Autêntica, 2013.

GOERGEN, Pedro. Pós-modernidade, ética e educação. Campinas, SP: Autores Associados, 2005.

IZQUIERDO, María Jesús. Uso y abuso del concepto de género. In: VILANOVA, Mercedes (Comp.). Pensar las diferencias. Barcelona: Universitat de Barcelona, 1994. p. 31-53.

LAHIRE, Bernard. Sucesso escolar nos meios populares: as razões do improvável. São Paulo: Ática, 1997

LISPECTOR, Clarice. A hora da estrela. Rio de Janeiro: Rooco, 2007. 
LOURO, Guacira Lopes. Gênero, sexualidade e educação: uma perspectiva pósestruturalista. 4. ed. Petrópolis, RJ: Vozes, 2001.

MARCONDES, Danilo; JAPIASSÚ, Hilton. Dicionário básico de filosofia. Rio de Janeiro: Jorge Zahar, 1996.

RAGO, Margareth. A aventura de contar-se - feminismos, escrita de si e invenções da subjetividade. Campinas, SP: Editora da UNICAMP, 2013.

\section{Sobre as autoras:}

Camila Santos Seimaru: Mestre em Educação pela Universidade de Sorocaba (Uniso). Especialita em Psicopedagogia. Graduada em Letras e em Comunicação Social - Jornalismo. E-mail: camilassan@hotmail.com, Orcid: http://orcid. org/0000-0002-7175-7663

Eliete Jussara Nogueira: Doutora e Mestre em Educação pela Universidade Estadual de Campinas (Unicamp). Graduada em Psicologia. Professora titular do programa de Pós-Graduação em Educação da Universidade de Sorocaba (Uniso). E-mail: eliete.nogueira@prof.uniso.br, Orcid: http://orcid.org/0000-0001-9178-221X

Recebido em novembro de 2018 Aprovado em maio de 2019 
